\title{
World Literature in Carniola: Transfer of Romantic Cosmopolitanism and the Making of National Literature
}

\begin{abstract}
From 1828-35, while Goethe was introducing his idea of world literature to the European public, Matija Čop and France Prešeren were engaged in the complex process of the cultural transfer of Schlegelian Romantic cosmopolitanism to Slovenia. In this way they hoped to ground the emerging and peripheral literature of Slovenia, tied to a national movement, in the universality of aesthetic humanism, and, by connecting it to the repertoire of European literary traditions from antiquity to Romanticism, to establish it as a modern classic at the world level. Čop and Prešeren, though without using the term, were realizing Goethe's idea of world literature. There is a strong probability that Čop was also familiar with Goethe's early remarks on Weltliteratur.
\end{abstract}

Philologist, literary historian, and librarian Matija Čop and poet France Prešeren are almost inseparable in Slovenian literary history. ${ }^{1}$ Their relationship has been interpreted as one of a figure and its background: the mentor's passive, bookish knowledge appears as the background to the creativity of the artist. However, the inseparability of their theoria and poiesis is not a coincidental feature in the genesis of Slovenian literature, but rather part of a wider pattern. The merging of thinking and poetry also characterizes early German Romanticism (the Athenäum circle, 1798-1800, especially the essays of Friedrich Schlegel), ${ }^{2}$ and this influenced not only Čop and Prešeren but also shaped the modern and postmodern tradition of aesthetic discourse of European literature in general (Lacoue-Labarthe and Nancy 1978; cf. Juvan 2006:

\footnotetext{
${ }_{1}$ This article is part of the project of the Institute of Slovenian Literature and Literary Studies at SRC SASA entitled "Slovenian" world literature: placing world literature in a national literary system (J63613), funded by Slovenian Research Agency (ARRS).

${ }^{2}$ In Fragment 116 from Athenäum, Friedrich Schlegel defines romantic poetry as "progressive universal poetry" whose "mission is not merely to reunite all the different genres of poetry, and to bring them into contact with philosophy and rhetoric. It seeks, and should seek, to mingle and, at times, to entirely fuse poetry and prose, genius and the analytical mind, , high-art poetry and folk poetry, to make literature living and social, and life and society poetic [...]" (F. Schlegel 1968: 140). He provided variations of the idea of a modern, Romantic hybridization of poetry and thought and of theory included in the self-reflection of poetry in other fragments, especially in "Dialogue on Poetry" from 1800 (F. Schlegel 1968); along with this, he also reiterated a mirror image - his thesis that poeticism is a discursive condition for philosophical and scientific thought.
} 
JUVAN

198-201). Self-reflection in the language of poetry or reflection of literary arts in theoretical-historical metalanguage was - also through the institutional practices of education - constitutive for the reproduction of aesthetic comprehension upon which conceptions of literature over the last 250 years have been based (Juvan 2011a: 27-34).

However, in this paper I will not deal with the connections between literary language and metalanguage from the aspect of the formation of aesthetic discourse, and I will also put to one side universalism in Schlegel's sense of the modern literary synthesis of genres, forms of speech, and different fields of knowledge. I will examine the work of Čop and Prešeren from the aspect of a different Romantic universalism - literary cosmopolitanism, through which writers of nationally understood literatures were believed to be able to synthesize varied literary traditions of the world and in this way become freed from classical imitation of the ancient classics (cf. Kos 1970: 106-109; 1979: 21, 34-35, 60-61, 79; Paternu 1994: 53-54). I will look at Prešeren the poet and Čop the "theoretician" from central European Carniola - at that time fairly provincial economically, politically, and culturally, though a not insignificant region of the Habsburg Monarchy - in the light of their role in setting up an aesthetically and nationally conceived literary system (Carniolan or Slovenian belle lettres). ${ }^{3}$ At the center of attention will be their choice to import and adapt practices from German literary cosmopolitanism. The strategy which they transferred to Slovenia from the aspect of Even-Zohar's polysystem theory represented just one of the historical realizations of a generalized pattern of asymmetric intercultural relations between core areas of world literary creativity (i.e. those which were established, linguistically and culturally strong, and with developed institutions and media) and peripheral (new, weaker) ones (Even-Zohar 1990; Casanova 1999; Moretti 2000, 2003; cf. Juvan 2009: 198200). Thus I will examine how Čop and Prešeren endeavored to place world literature in the emerging Slovenian literary system, even as they also attempted - at least at the level of aesthetic and imaginative potentialities - to include domestic literature in the world literary system, which during the period of Romanticism was similarly still in the process of structural emergence. It is thus about the role of their poetic language and "theoretical" metalanguage in the mutual shaping of two artistic fields, the world and the national (cf. Juvan 2009: 188-190). This process of course was not just Carniolan/

\footnotetext{
${ }^{3}$ It was clear to Stritar "that 'Carniolans' are 'Slovenes' to our poet [author's note: Prešeren] and that the expression Slovenes is often used to refer to all Slavs." (Stritar 1955: 22)
} 
Slovenian but also transnational, European, influenced in particular by the tradition of the cosmopolitan network of literati (Respublica litteraria) and Romantic national movements, characterized by currents of cultural nationalism and by their search for a compromise between the linguo- or ethnocentric individualization of literature on the one hand and its semanticaesthetic, imaginary universalization on the other.

From the famous French Querelle des anciens et des modernes on we can observe the decline of the undisputed authority of classical ancient standards and the assertion of the culturally and historically variable individuality of aesthetic taste. This aspiration in the literary field towards the end of the Enlightenment coincides with Herder and Humboldt's cosmopolitan conception of nations as mutually equal collective individuals with linguistic and cultural differences, each contributing in their own way towards the shaping of a universal, or in other words European or world, humanistic culture (cf. Koch 2002: 83-143). More recent research on nationalism has shown that nations as a characteristically modern, post-Enlightenment type of community in $19^{\text {th }}$ century Europe took form and became individualized through differentiation from other ethnically based societies, i.e. they arose internationally, so to speak and - regardless of the mutual conflicts and belief of every nation in its own Sonderweg - according to nearly the same set of models (Leerssen 2006a). As Miroslav Hroch, a leading historian and theoretician on nationality, concludes, nations in Europe were built as forms of communities which are internally connected by now one set, now another set of "objective" ties (economic, political, linguistic, religious, geographical, or historical), but also ideological factors, i.e. "subjective" feelings of belonging and collective consciousness. Crucial to the social cohesiveness of nations, in his view, are a collective memory of a common historical destiny, a certain density of linguistic or cultural ties which reinforce communication within the group, and an aspiration for the equality of citizens arising from the Enlightenment (Hroch 1993: 4-5). Nations, observes Hroch, are not merely an "invention" of the $19^{\text {th }}$ century or newly "imagined communities", since the ideological imagination of the collective was based on actual traces of memory and remnants of material bases, which shaped ethnic consciousness from the late Middle Ages on - for example, on the tradition of a literary language and customs, provincial or feudal belonging, residual nobility and a memory of a former "state" autonomy (8-9, 13).

At the level of the modern formation of nations that we are referring to here, in Hroch's view European ethnic communities were in an unequal position. On 
JUVAN

the one hand these were peoples (especially from central and eastern Europe, and from northern Europe, too) which up until the end of the $18^{\text {th }}$ century lived in a subordinate position in monarchies headed by "foreign" ruling classes, while on the other they were peoples (mainly western European) whose nobility and rulers came from their own ranks and which after the bourgeois revolutions gradually formed their own national states in parallel with the restructuring of monarchies into constitutional, more democratic bourgeois societies (5). Central and eastern European nations which were already characterized in the $19^{\text {th }}$ century as "un-historical" and among which Slovenes also belonged, had to be created differently, through national movements. These according to Hroch passed through three phases: Phase A was characterized by philological, scholarly, and literary activities by a few intellectuals, who discovered, invented, raised awareness of and provided evidence for the main attributes of national communities and their historical continuity (language, literature, history, mythology and folklore, customs, territory, and religion); in Phase B politically more engaged actors, who address a wider public and explicitly strive for some sort of cultural, administrative or state autonomy, are included in the "revival" activities; Phase $\mathrm{C}$ is constituted by mass movements catalyzed by the upward social mobility of the bourgeoisie and intellectuals, the political-moral crisis of the old regime and religion, and growing social tensions which in simplified form are articulated in national categories $(6-7,9)$. In this phase cohesion within a national movement and the formation of an entirely ethnically based social-professional structure were enabled mainly by print media, spatial concentration of communication in an ethnic literary language, one's own cultural and scientific institutions, intellectual and bourgeois societies, and mass "revival" movements and political rallies (Hroch 1993: 11-13). The Slovenian national movement in which Čop and Prešeren also took part belongs, in Hroch's view, to the second European type (along with Lithuanians, Latvians, Croats, Slovaks and Ukrainians), in which Phase B began already under the old regime (in Slovenian in the 1840s), and became a mass movement only after the introduction of constitutional reforms (Hroch 1993: 8).

Regardless of such typological differences and other idiosyncrasies, stateless national movements as well as many ethnic groups that built their national identity upon already established state structures both fashioned their particular individualities in an almost uniform way in the $19^{\text {th }}$ century, since one after another they epidemically imitated the same matrix of cultural nationalism. In conformity with the ideology that Herder and Humboldt disseminated 
throughout Europe, the pillars of every nation are its own language, collective memory, a tradition of folk and learned culture, and especially history, art, and literature (Leerssen 2006a: 146-147 passim, 2006b). As I have already noted, no nation formed its particular features in isolation, but rather - according to the logic of identity construction - through comparisons with other "imagined communities", in other words, through differentiation, rivalry, disputes and alliances with other nations (cf. Casanova 1999: 56-59; Juvan 2008: 64-65, 75-77). All of this was reflected especially in literature.

The cultural individualization of nations is also articulated in the literary field through cosmopolitan conceptions of world civilization as a uniform "generally human" system and through the study of the historical connectedness of the literatures of Europe and the world. ${ }^{4}$ As we will see, the framework of literary cosmopolitanism with its ethical-political and aesthetic-poetological implications defines Goethe's formulation of the concept and program of Weltliteratur, and around 1800 inter alia great world historical accounts of literature written by the typically cosmopolitan Madame de Staël (De la littérature, considérée dans ses rapports avec les institutions sociales, 1799/1800), Friedrich Bouterwek (Geschichte der Poesie und Beredsamkeit seit dem Ende des 13. Jahrhunderts, 12 volumes, 1801-1819) and Friedrich Schlegel (Geschichte der alten und neuen Literatur, 1815). ${ }^{5}$ These extensive essays - Čop carefully studied the works of Bouterwek and Schlegel, referred to the works of de Staël and even excerpted from them (Kidrič 1978: 156-157; Kos 1979: 35-36, 94, 97; Čop 1986: 127, 130) - liked to employ universalistic concepts (for example "world history", "European literature", "world civilization”, "European civilization"), but the expression "world literature" is not to be found there. Nevertheless, they tried with their stories of organic socio-spiritual development to arrange leading European as well as "Oriental" literatures into a coherent system. They observed from a comparative standpoint their typological characteristics, contacts, imitation, intellectual exchange and hybrid intertwining. ${ }^{6}$ Such works of early Romantic aesthetic erudition from the aspect of historicism broke with the classicist tradition and the universal model of Greek and Roman

\footnotetext{
${ }^{4}$ On 19th-century and more recent histories of world literature (Hermann, Hettner, Scherr, Stern, etc.) see D'haen 2011: 16-25.

5 On Schlegel's approach to world literary history see Pizer 2006: 12-13, 41-43.

6 Schlegel's section "Epochs of Literature" from "Dialogue on Poetry" (F. Schlegel 1968: 60-80) acts as a proleptic summary of his own narratives from History of Old and New Literature, and is also similar to the development concept from the nearly contemporary work On literature in light of its relationships with social institutions by de Staël (who was to be "mentored" beginning in 1804 by Friedrich Schlegel's brother August Wilhelm).
} 
JUVAN

antiquity. Through an obsessive comparison of "ancient" and "modern" they demonstrated the uniformity and progress of European civilization. Through the development and cultivation of vernaculars, individualized and specific "new" national literatures (from Italian to German) were to emerge in historical order from the shadow of the absolutism of antiquity, demonstrating their European and world significance in their mutual competition. Instead of antiquity, the role of the universal framework was acquired by the emerging canon of European and world literature, in which medieval and modern age writers using the vernacular gradually came to prevail.

In Schlegel's History, which attempts "to sketch a picture of the whole of European literature" taking into account eastern civilizations, a "historical viewpoint comparing nations according to their value" is established through the universal optic of "world history"; this value is shown above all in literature as "the epitome (Inbegriff) of all intellectual capacities and products of a particular nation" (Schlegel 1815: 6, 15). A world horizon in Schlegel's view thus comparatively determines identity, value position and the changing historical role of "national literatures".

This kind of connection of the nationally individual and the universal is also characteristic of Goethe's fragmentary and ambivalent characterizations of the notion of "world literature" from 1827-31, scattered partly in his articles for the review Kunst und Altertum, and partly published only in 1836 in Eckermann's Conversations of Goethe (cf. Strich 1949: 349-351; Pizer 2006: 18-46; Juvan 2009: 182-188; D'haen 2011: 6-12, 27-33). Since nations created their (literary) identities comparatively, through hermeneutic reflection of and differentiation from other ethnic communities, ${ }^{7}$ which similarly became conscious of their nationhood, world literature according to Goethe's concept could also not be something built upon already existing national literatures. In his book Weimaraner Weltbewohner Manfred Koch notes that "the shaping of consciousness about national literatures is always already taking place from the perspective of world literature" (Koch 2002: 14).

World and national in Goethe's time were in fact two sides of the same ideological coin. On the one hand, the dangerous conflicting of nationalisms was sublimated by a cosmopolitan ethics and aesthetics of the early $19^{\text {th }}$ century in concepts such as "European civilization" or "world literature". These were assumed to provide a universal humanistic basis for understanding difference

\footnotetext{
7 On Goethe's notion of reflecting national literature in the ethnic and cultural otherness of foreign literatures see Strich 1949: 18-19.
} 
and generating tolerance among nations, while at the same time applying general humanistic and aesthetic values which transcended national particularities, and a consciousness of the historically created unity of Europeanism (cf. Strich 1949: 32-40). Concepts of European culture and general human intellectual achievements thus operated in a particular nation as a standard for comparison with past and contemporary achievements of other ethnic communities. On the other hand, the idea of the nation remained the premise and ultimate objective of all cosmopolitan discussion of a European spirit, world civilization, and world literature. Although Goethe persistently proclaimed humanist ideas about the "generally human" and world literature as the common property or value meta-canon of humanity, in the same breath he typically advocated for a more visible international position of German literature through introducing the concept of Weltliteratur, appealing to his fellow writers to adopt the available world sources for the needs of domestic aesthetic development (cf. Eckermann 1998: 164-167; Goethe 1974: 457-459). The worldly openness towards linguistic and cultural otherness - in fact mediated through aesthetic discourse, Eurocentrically generalized to all literatures from all times - meant for him an essential condition for the renewal of national literatures. It was especially important to go beyond individual self-sufficiency in a new "epoch of World-literature" (Eckermann 1998: 165), when industrialization and the expansion of the world capitalist market synchronously gathered together the varied linguistic and cultural traditions of the world before European readers and artists (cf. Koch 2002: 3-4). Goethe's metaphorical analogy of "intellectual exchange" with Smith's liberal economic idea of the free circulation of goods and exchange value on the world market according to Hörisch perhaps also indicated a "semantic inflation" arising due to the excess supply of printed literature (Koch 2002: 15). ${ }^{8}$ With respect to this Koch sees in the poetological poems, intercultural intertextuality and orientalism of Goethe's West-östlicher Divan (1819/1827) the promising realization of the modern, "globalized" version of classicist poetics (Koch 2002: 177-229). Through it Goethe successfully responded to the early challenges of an accelerated world expansion of ideas, texts, and other cultural products.

With a cosmopolitan modern classic such as that represented by Goethe, the individuality of the nation and of the writer, who through his literary activity contributes to the shaping of his nation, are established in a different

\footnotetext{
8 Goethe's (and Marx's) parallels between the intellectual traffic of works of world literature and the international capitalist market, which are currently so widely exploited (cf. Casanova 1999; Moretti 2000; Damrosch 2003, and many others), were noticed already by Strich (1949:31).
} 
JUVAN

and by no means self-sufficient manner: through the creative acceptance of initiatives from other national literatures and non-European civilizations. ${ }^{9}$ The cosmopolitan, but essentially Eurocentric type of the new classic as exemplified by Goethe clearly impressed Čop early on, to such an extent that on 13 December 1822 in his youthful letter to his friend Savio, who was enthralled by the "Orient", he included an annotated quote from Divan (from the part "Hikmet Nameh. Buch der Sprüche"). This fragment encapsulates Goethe's universalistic conception of the understanding of one's own, clearly European culture (i.e. the "western" Calderón) through an apprehending of the "generally human" essence in artworks from distant literary worlds (the "eastern" Hafez):

»Herrlich (zwar, heißt es im Divan) »ist der Orient

Uibers Mittelmeer gedrungen,

(Doch) Nur wer Hafis liebt und kennt,

Weiß, was Calderon gesungen!« (Čop 1986: 54).

In general we can agree with Koch that Goethe's definitions of world literature have three dimensions: first, they are a historical diagnosis of a new, industrial age, characterized by a global cultural market and the growth of transnational exchange of intellectual goods (texts, ideas, forms); second, they are a cosmopolitan moral appeal for intercultural understanding among nations and their political reconciliation; and finally, they are also a poetics which tries to orient the modern poet towards a new horizon, at a time when a multitude of historically and spatially differing world traditions become simultaneously available (Koch 2002: 4). On all three levels Goethe resolves the tensions between Herder's concept of Nationalliteratur and his own newly coined Weltiteratur, which arose based on the less well known Wieland's and Schlözer's uses and an analogy with the lexical family of derivatives based on Welt-, which particularly in economics vocabulary was expanding around 1800 (Koch 2002: 2; D’haen 2011:5).

Thus for Goethe world literature meant the growing international exchange of literary works shown in contacts among literati from different countries, in the establishment of possibilities for intercultural understanding, in trade in books, translations, stage performances, reviews and in the cosmo-

\footnotetext{
9 According to Todd Kontje, Goethe referred to or creatively rewrote not only Hafez, but also Shakespearean drama, Pindaric odes, Roman elegies, and many other source texts, which in turn made him interesting for foreign audiences (Pizer 2006: 21).
} 
politan imagination and citationality of modern literary texts. It was precisely this newly experienced emerging space that in Goethe's eyes made it possible for a national literature - including a "latecomer" such as German - to assert itself as an original producer or a competent translator and mediator beyond its borders, but without this (peripheral) position determined by the existing hierarchy of the classical canon and its earlier Middle Age and modern era heirs. Moreover, self-conscious collaboration with transnational social networks of literati and joining the cultural market at the very dawning of the world literature epoch allowed Goethe to promote his semi-peripheral hometown Weimar not only as the intellectual center of politically and culturally fragmented Germany, which was lagging behind Western nations, but as an important node of the evolving world literary system at large. Or to use Strich's words, which - quoting Goethe's own expressions - come quite close to present-day world-system approaches:

For that is what the world literature which developed during Goethe's later years really was, the world-wide expansion of the little circle round Goethe. Goethe remained the central point round which the literatures of Europe revolved, and Weimar became the intellectual capital of Europe. Writers of every nation acknowledged their debt to Goethe, honoured him as their intellectual father, the leader of the intellectual life of Europe, and Weimar was the spot to which not only the writings of European authors came, but to which they themselves made pilgrimage. The Goethe-house in Weimar was the focal point at which converged writers from France, England, America, Italy, Scandinavia, Russia and Poland. The little worldsystem, the microcosmos Weimar, had grown to a great worldsystem, a macrocosmos, in which the planets of the intellectual universe revolved round the fixed star, Goethe. (Strich 1949: 50-51; emphases added.)

A converse condition for this kind of assertion in the world space as Goethe conceived it is that the national literature not close itself off but rather that it appropriate cultural material from other parts of the world and recognize within the foreign elements a different individualization of the "general human"; thus national literature also co-creates universality precisely through joining the literary world (cf. Eckermann 1998: 164-167).

Before moving to an explanation of how Goethe's kind of literary universalism and the idea of a world literature (the Schlegel brothers, Goethe's great admirers, were close to him with respect to both) were productive for Slovenes, a short methodological digression is needed. The cosmopolitan 
JUVAN

experience of world literature as international cultural traffic in the decades after Goethe had some influence on the formation of a new literary historical discipline, comparative literature, although the latter - impressed by positivist search of rapports de fait characteristic of the dominant "French school" remained in a rather ambivalent relation to world literature as a field of study and a teaching subject (cf. D'haen 2011:47-73). ${ }^{10}$ Whereas comparative literature for a long time explained the interaction of literatures in particular by means of bilateral actual contacts, literary mediation and influence (cf. Ocvirk 1936: 118-182), postmodern comparatistics, in the face of the challenges of globalization, the crisis of the capitalist neo-liberal paradigm, the "war on terror", multiculturalism, and post-colonialism, addresses world literature through the transcultural deconstruction of concepts of the national and the international. Comparative studies can use in place of influence more precise conceptions articulated in recent epistemologies. One such conception - in addition to intertextuality, interliterariness or creative reception - is cultural transfer, which has been known in comparative historiography since the late 1980s (cf. Kaelble and Schriewer 2003; Cohen and O'Connor 2004). The subjects of cultural transfer are not only texts, but also actors, products, practices, media, concepts, value systems, institutions, etc. In contrast to influence, transfer observes the social facticity of processes in the culture influenced. It assumes an awareness of the differences between the repertoire of the receiving environment and that which is offered as the source. When the comparison with the potential source shows a lack, then the need for importation arises, and strategies of transfer take shape - from dealing with the defense mechanisms of the receiving environment through processes of appropriation, creative transformation and the adaptation of the imported models to new functions and meanings to explicit commentary and evaluation of the foreign element in the target society. The process of cultural transfer frequently leads to the naturalization of the foreign element, which then becomes perceived as an autochthonous structure. As already stated, the subject of transfer can also be a broader concept, which organizes a ramified system of knowledge, texts, products, and activities.

\footnotetext{
10 World literature, which was and still is studied and taught mainly through translation, was criticized for being too broad and too shallow for an expert in comparative literature who is supposed to be fluent in at least three foreign languages and a connoisseur of at least two national literatures including their detailed historical contexts. On the other hand, however, world literature, with its complex and plural interactions and cosmopolitanism, was a challenging ideal of comparative literature ever since Hugo von Meltzl's 1879 initiative of Acta comparationis litterarum universarum.
} 
In the continuation I will outline an important case of Slovenian cultural transfer: how and with what objectives did Čop and Prešeren - Romantics from one of the peripheral, small European literatures caught up in the first two phases of nationalist movements and thus connected with narrow circles of national revivalist intellectuals - become included in the "age of world literature" detected in Weimar by the cosmopolitan Goethe? I will show how in Slovenian lands in the 1820s and 1830s the cultural transfer of German Romantic universalism took place, and, through this conception, the world ensemble of representations and forms set in on which the modern, individualized poetics drew, in an attempt to achieve the status of the classic and provide a foundation for national individuality in poetry. I will look at how Čop and Prešeren, the main actors in this transfer, viewed the repertoires, ideological conditions, and needs of Slovenian literature, which was still in the phase of media, institutional, and systemic emergence, and situated in a society in which the language of communication in public, official, and educational institutions was mainly German, the language of the ruling ethnicity. In the environment of a small language faced with the dominance of German, the world comparative view - about which Friedrich Schlegel wrote in History, and Matija Čop practiced following Schlegel's and Goethe's example - triggered an even more painful feeling of inadequacy, the absence of national classics, and being left behind than in Goethe and among other Germans when at the beginning of the $19^{\text {th }}$ century they entered into a literary rivalry with the richer and earlier traditions of the Italians, Spanish, French, and English.

Scholars of Prešeren have found that Čop and Prešeren were attached to the cosmopolitanism of early German Romanticism, in particular to the ideas of the Schlegel brothers, in the culture planning and establishing of an aesthetically autonomous national literature (Žigon 1914: xvi-xvii, xxxvi-xxxviii, cliiclxx; Kidrič 1987: 154-158, 1938: xlvi, lxxiv-lxxv, cxxi-cxxii; Kos 1970: 104141, 1979: 34, 94-98; Paternu 1994: 48-61). ${ }^{11}$ In the first quarter of the $19^{\text {th }}$ century, August Wilhelm and Friedrich Schlegel developed a program of Romantic universalism and cosmopolitanism with aesthetic-philosophical, philological, literary historical, translation and poetic aspects, and also brought it to fruition. ${ }^{12}$ Similarly to the Weimar classic Goethe, their somehow patronizing

11 On the notion of culture planning see Even-Zohar 2008.

12 Cf. their critical essays, philosophical fragments and lectures with aesthetic and literary historical content (Friedrich's Gespräch über die Poesie in Geschichte der alten und neuen Literatur, August Wilhelm's Vorlesungen über schöne Literatur und Kunst in Vorlesungen über dramatische Kunst und Literatur); translations and publication of Romance literatures, study and translation of Indian 
JUVAN

source of inspiration and correspondent, they saw in the multilingual traditions of world poetry a foundation for the individualization and "cultivation" of both the modern literary writer as well as of their own national literature. It is well documented that Čop and Prešeren - like some of their German-Austrian contemporaries - followed the commitment of the Schlegels to the literaryaesthetic refinement of their literary language through the adoption of medieval and Renaissance Romance poetic forms, understood in their authentic linguistic expression and semantics (Kos 1970: 38-54, 106-107, 126-132, 1979: 94-95; Paternu 1994: 51-53). There is no agreement in Prešeren scholarship as to whether they also accepted the Schlegelian idea of Romanticism as a synthesis of the antiquity and the modern (Kos 1970: 117-120; Paternu 1994: 54-57).

Despite this, it is clear that antiquizing tectonics and a touch of classicism in Prešeren's poetry make it possible for modern, individual subjectivity, through the use of the historical perspective and stylizations, to be articulated in a classical manner (similar to Goethe's), through objectivizations in the heterogeneous materials of European and partly also world heritage. The spontaneous, natural originality of the peripheral national poet, connected with the philological-literary and intellectual beginnings of the Slovenian national movement, is thereby elevated in the universalistic framework and is placed at least imaginarily at the center of the emerging world literary system. Also because the entirety of Slovenian "young literature" was metonymically represented in Prešeren's persona and work, the critic Stritar in 1866 attributed the role of "national poet" to him (cf. Nemoianu 2002: 254-255; Juvan 2011b). The structural whole of Prešeren's volume Poems (1847) thus in fact universalistically synthesizes the topics, forms, metaphors, themes, and modalities taken from ancient Greek-Roman and Judaic traditions, from Romance and Germanic ones from the Middle Ages, the Renaissance, and the Baroque, as well as from more modern currents of pre-Romanticism, Romantic Byronism and Orientalism, Slavic national Romanticisms, and Biedermeier.

The process of Čop's and Prešeren's cultural transfer of Romantic universalism took place mainly between the years 1828 and 1835, when the two friends regularly got together in the provincial center, the petty bourgeois town of Ljubljana, whose public space bore a noticeably German appearance. Through the transfer mentioned, the emerging national belles lettres, written in

literature (August Wilhelm's collection Blumensträuße italienischer, spanischer und portugiesischer Poesie, the newspaper Indische Bibliothek) and August Wilhelm's original poems written in Romance forms. 
a small, socio-linguistically subordinate language, was constituted in aesthetic and imaginary terms as an equal part of world literature, joining its historical and contemporary developments through locally specific transformations of its repertoires, from a peripheral position. The practices and repertoires of world literature were accepted through adoption of Goethe's and the Schlegel brothers' models of literary cosmopolitanism. That this kind of universalism was elaborated in the language of and for the needs of the literary culture of Germans, an ethnicity which also ruled the Slovenian population of Habsburg Carniola and linguistically dominated its public sphere, clearly did not bother Prešeren and Čop: they were typical protagonists in the earlier phase of national movements which as a rule were not yet familiar with nationalistic exclusiveness and politically explicit demands for autonomy. The objectives, strategies, and implementation of the transfer of world literature to a locally specific Slovenian literary system originated from Čop's and Prešeren's evaluation of the history and current social position of Slovenian language and literature, and they had to consider the ideological reality at the time.

After returning from the Galician Lviv, Čop changed from an aesthetic appreciator of European literatures compelled to earn a living from the dull profession of teaching into an actor in the Slovenian literary field (cf. Kidrič 1987: 157-161; Kos 1970: 38-40, 1979: 32, 36-37, 124-131, 137). Upon moving to Ljubljana, he used the comparative perspective, from which he had earlier merely observed the achievements of the European literary past and present, to influence the relationships between Slovenian literature, Europe, and the Slavic world. In this light he and Prešeren considered the cultural circumstances of provincial Carniola to be lagging behind, and the current state and prospects of Slovenian literature as limited by the public predominance of German and the religious-utilitarian needs of the largely illiterate population, whose educated and culture-creating class had for centuries been made up almost exclusively by the clergy, and whose rare consumers of literature in the Slovene language were also literate peasants. ${ }^{13}$ Existing concepts of national awakening in Carniola, which arose under the influence of the renowned Viennese Slavist Kopitar and domestic Jansenism, were still physiocratic and

\footnotetext{
${ }^{13}$ Cf. Čop's letters to Pavel Josef Šafárik (24 June 1831, 27 June 1831), Jernej Kopitar (January 1828, 16 May 1830, 28 April 1833, 2 May 1833, 12 May 1833, 17 June 1833), František L. Čelakovsky (14 March 1833), and especially his polemical-programmatic essay "Nuovo discacciamento di lettere inutili, to je: Slovenska abecedna vojska” from 1833 (Čop 1983: 47-49, 59-61, 66-67, 70-73, 73-74, 75-77, 77-79, 83-85); Prešeren connoted such assessments in his poems, such as "Pevcu", "Orglar", "Nova pisarija" and "Glosa" (Prešeren 1965: 41, 91-92, 99-106, 111-112).
} 
JUVAN

philological, based on the idea of Slovenes as a peasant people, and moreover imbued with a provincial moralism relying on a narrowly interpreted set of Catholic morals. From this aspect, it was considered adequate for the needs of Carniolan literature to standardize the grammar and orthography and purify the literary language, which was based on the spoken language of peasants, the collection of "decent" folklore songs and stories, and the printing of literature whose aesthetic "pleasure" was subordinated to "utility", instructiveness, guidelines for bringing up children, and reinforcement of religious faith (cf. Kos 1979: 120-170; Paternu 1994: 107-126).

As a result of this perception of a domestic lack, Čop and Prešeren felt the need for the introduction of a strategy tested in the cultural nationalism of Germans and other better developed zones of the world literary system, especially among the Poles and the Czechs. Čop, who along with Prešeren both had experience living in foreign, multinational cities with a lively cultural life - found the autarky of the prevailing linguistic- cultural policies in Carniola difficult to bear, appreciated Goethe's "European orientation" (Kos 1979: 79), by means of which he resisted similarly purist aspirations of some German national revivalists and Romantics for autochthony and self-sufficiency (Pizer 2006: 40-41, 44). For this reason as well he was probably that much more enthusiastic about the transfer of the cosmopolitan ideas of the national Romanticism advocated by the Schlegel brothers, who, however, in comparison to Goethe's cultivated cosmopolitan outlook, were more German-oriented (Pizer 2006: 41-44).

Following the example of Friedrich Schlegel, Čop and Prešeren wanted to attract to Slovenian literature members of the domestic educated class, who were integrated into a "foreign" German culture, and develop the Slovenian literary language through its use in science, art, polite conversation, and high culture. Cop articulated these ideas for the first time publicly, as well as most coherently, almost in the form of a cultural program, in his introduction and appendix to the translation of Čelakovskýs review of Krajnska čbelica, which was published in February of 1833 in Illyrisches Blatt. ${ }^{14}$ In this work Čop regarded poetry such as that represented by Prešeren as discourse which is

\footnotetext{
${ }^{14}$ In this regard Čop was probably the first in Slovenia to use the argument "from outside" for "internal" needs (similar to what Goethe was doing in Germany; cf. Strich 1949: 21): the importance and value of Krajnska čbelica and Prešeren was taken as evidence for the favorable reception abroad, in a larger and more developed environment - i.e. at the threshold of world literature (Čelakovský printed a review of KČ together with a literary historical sketch of "Carniolan literature" and his own translations of five of Prešeren's poems on pp. 443-454 of the journal Časopis Českého museum in 1832, among popular science essays on astronomy and history).
} 
dependent primarily on the individual talent of its creators and does not need a nationally profiled infrastructure of media and cultural institutions, nor even a background of a literary language differentiated by genre (Čop 1983: 110123). Since neither one yet existed in Carniola, poetry for Čop was the fastest route by means of which intellectual culture expressed in the Slovenian language could catch up to developed Europe and make possible the constituting of Slovenes as a modern cultural nation (cf. Kos 1979: 155-170). In this sense Čop envisioned that poetic art could be perfected through the model of universalism - with the individualistic and reflected intertextual emulation of the traditions of European literatures which were already recognized as important on a world scale and on a par with the ancient classics. The deficiency of actual social heteroglossia in Slovene would be compensated for by the internal aesthetic-stylistic saturation of poetic language which absorbed the world into the native language.

Čop and Prešeren's transfer of universalism and the local inscription of the Schlegelian version of world literature to Carniola encompassed a ramified complex of activity. They collaborated in the organization of an institutional and media foundation for the promotion of Slovenian belles lettres (the poetry almanac Krajnska čbelica, 1830-34). Čop looked after the material presence of world cultural repertories by systematically building up the inventory of the Ljubljana lyceum library and enriching his personal library. Along with Prešeren he joined the cosmopolitan respublica litteraria: through personal interactions and written correspondence they participated in domestic and international social networks of supporters of the development of aesthetic literature. Some foreign correspondents, in particular Čelakovský and Šafárik, presented the achievements of older and new Slovenian literature in their environments. ${ }^{15}$ This crossing of domestic boundaries and the active presence of Slovenian literature in another language and literature (through reviews, translations, transnational literary histories and literary scholarship) were significant since in both we can see the first steps of Slovenian literature into the world literary system, according to Damrosch's criteria (2003: 4, 15-17). Actors in the Slovenian literary field, who were in contact with the national

\footnotetext{
15 The mentioned review of $K \check{C}$ and translations of Prešeren by Čelakovsky in Časopisu Českého museum (1832), one of the typical media which enabled the international flow of literatures through translations, news, reviews, and essays; Šafárik placed Čop's historical overview of Slovenian literature in revised form at the beginning of the first notebook in his review of south Slavic literatures (Geschichte der südslawischen Literatur I), which was published in Prague only in 1864. Šafárik's work is an example of earlier transnational literary historical syntheses and handbooks, with which world literature was also later established in university research and teaching practices.
} 
revival circles of other Austrian Slavs, were included in the world literary republic at the outset not only as recipients but also as producers of cultural goods which circulated in international exchange, albeit somewhat uncertainly. Individual pieces of Slovenian literature, through translations, reviews and stage performances, trickled for a long time into neighboring or relatively peripheral areas of the world literary system, the structure of which forced small and peripheral literatures such as Slovenian into a position of recipients of metropolitan initiatives (cf. Casanova 1999: 28-40, 63-65; Moretti 2000: 5566; Juvan 2009: 191-201). ${ }^{16}$

Texts which planned and publicly defended the use and adaptation of the imported model for the needs of shaping a national literature, and attempted through ideological struggle with influential cultural politics to find a space for it, were crucial for the Slovenian transfer of Romantic universalism. These were either literary historical, aesthetic-critical, poetological, comparative or philological reflections and polemics (Čop's correspondence with Kopitar and appendix to the translation of the Czech review of Kranjska čbelica, later included in Nuovo Discacciamento di lettere inutili, das ist: Slowenischer ABCKrieg, 1833), or literary citationality, self-referentiality and satire in Prešeren's poetry, as well as his translations of modern European poets (Bürger, Byron and Mickiewicz). Prešeren formed his poems using intertextual evocations of European traditions and awakening of cultural memory, embodied in the western canon. He further embedded self-reflection of these transfers figuratively in his verses. He poetically reflected on his own poetry, his predecessors, rivals, and colleagues (especially from the Krajnska ćbelica circle) against a horizon of conceptions of world literature, using the criteria of ancient, medieval and modern age European classics and through comparisons with modern poetic tendencies in other nations. In short, in his classical Romantic period of creativity, Prešeren tried to base national identity on literary

\footnotetext{
${ }^{16}$ A Cobiss bibliographical review of translations of Prešeren shows how as the leading Slovenian classic he gradually and on a smaller scale "conquered" the linguistic-cultural spaces of the world literary system: first, in 1865 , he entered the German linguistic space, but with a printing in Ljubljana (he wrote in German from 1827 on and translated his own poems into that language); German publications followed, which spatially move further and further beyond Carniola (Graz in 1871, Vienna in 1901, Leipzig in 1923 etc.); before the end of the $19^{\text {th }}$ century Prešeren had been translated only into Czech (Jičín 1882), but the $100^{\text {th }}$ anniversary of his birth served to stimulate somewhat translation (and along with it his presence in other literatures: into Serbian (Belgrade 1900, 1929, 1932 etc.), Russian (Moscow 1901, 1948) and Ukrainian (Peremišl 1902). Presešren was translated into today's leading language of the world literary system, English, first in 1919 (published in Ljubljana), and with a published book he was accepted into the heart of the system (Oxford) only in 1954 , and even then with just a modest print run.
} 
cosmopolitanism. In accordance with Čop's adaptation of Schlegel's outlooks in his poems, Prešeren in his self-referential, satirical, and poetological poems adopted the model of a universal "world" aesthetic poetry and transferred it to Slovenian literary language, which would then through the development of the aesthetic function enable the flourishing of bourgeois-educated culture as the basis for national individuality. Prešeren's poetry acted as the beginning of the realization of culture planning characteristic of Čop's circle: the author through his poetry also himself attempted performatively to establish a context which would enable its existence and reproduction. The tension between the aesthetic universalism of Romantic poetry and the socio-economic and cultural-political actuality of a semi-peripheral environment also generated sarcastic and satirical burlesque, elegiac resentment, a drive towards utopia or a retreat into the aestheticized historical stylization of amorous feelings.

During the process of cultural transfer, Matija Čop offered his friend Prešeren philosophical, historical and comparative aesthetic knowledge as well as the fund of his private library and that of the lyceum. The role of mediator (Kos 1970: 38-54), such as the one he played in Rijeka and Lviv between foreign languages and literatures (German and Romance, English and Slavic, etc.), he now performed between European and Slovenian literature, universalism and national revival. A whole series of Čop's activities and conceptions in fact embodied Goethe's cosmopolitan idea of world literature as intercultural circulation on a globalized market and a frame of reference in which identities of particular national literatures are shaped or renewed. Such were Čop's planned philosophical and literary historical studies, and his knowledge of 19 languages, intended for the aesthetic comprehension of literature in authentic linguistic-historic expressions. Čop's international correspondence, the medium for the transfer of facts, metaliterary observations and aesthetic discourse, arose in the spirit of the Republic of Letters. He enacted Goethe's metaphors of world literature as a market with his international exchange and purchases of books, with which he systematically built up his personal library and the library of the Ljubljana lyceum, for which as librarian he also systematically organized the catalog. Čop designed his personal library, which contained 1993 volumes, entirely in the spirit of world literature. To Čop, Nethersole's lucid view on libraries as archives, sources, and tools of writing or exploring world literature could be rightfully applied:

As sites encapsulating and recording specific flows of symbolic and cultural capital as well as offering tools with which to access it, libraries great and small, 
famous and almost forgotten, real, imagined, and virtual, are the receptacle of the world's scriptural memory. They are the place best suited to learning how to read the process of recording and recounting individual and collective encounters with the world, derived from and shaped by the commerce of books in different parts of the globe that together produce an increasingly connected cosmopolitan universe. (Nethersole 2011:314)

Čop conscientiously and carefully collected books in many languages, especially those corresponding to aesthetic discourse: the latter was reflected on by literary historical, aesthetic and poetic essays and embodied by works of the Greek and Roman classics through leading authors of the European Middle Ages, the Renaissance, Mannerism and the Baroque to modern Romantics (Kidrič 1987: 148, 156-158; Žigon 1917). Although Čop's library had the imprint of linguistic-cultural and aesthetic cosmopolitanism, it also included works in support of the idea of national awakening, particularly among the Slavs. Thus Čop's personal library as well as the lyceum library that he headed were significant sources for Prešeren's creative work, not only in terms of their content but also in the cosmopolitan logic of their "order of books" (Chartier 1994). The personal library left behind after the poet's death was far more modest in extent than Cop's, consisting of only a bit more than a hundred books, many of them likely having disappeared even before the probate. ${ }^{17}$ Goethe's idea of world literature was further concretized by Čop through his following of European cultural journals, most consistently Goethe's own Kunst und Altertum, a journal on the literary arts of Germany, Europe and the world published from 1816-1832. But in the case of journals as well, Čop was not merely a passive consumer of European literary developments, he also began to be actively included in the exchanges among different literary spaces in 1827 and 1828. He sent notices about the Vienna book market to the Lviv journal Rozmaitości; his letter about Bowring's English anthology of Polish poetry was the basis for an article by Wacław Zaleski (Štefan 1985). When the Vienna court librarian Kopitar took over the editorship of (Wiener) Jahrbücher der Literatur - a quarterly which in terms of its content (publishing the works of among others Goethe and August Wilhelm Schlegel) was perhaps Austria's most cosmopolitan journal, despite Metternich's patronage and conservative

\footnotetext{
17 It is interesting that of modern Romantic literature it was possible to find only the works of Byron and Thomas Moore in Prešeren's library; he had a much larger collection of ancient, medieval, and modern era classics (cf. Kos 1970: 33-35). Perhaps this intimate closeness with personal books also indicates why the Romanticism of Prešeren is so "classical", different from other European Romantics.
} 
program - he invited Čop to collaborate in 1828, but due to their quarrel in the 1833 Alphabet War nothing came of it, despite Čop's having prepared considerable and diverse material for literary reviews (cf. Kidrič 1987: 160161). Not least of all, Čop's historical observation of the development of European and non-European literatures in mutual connection, especially through translations, belonged in Goethe's context. Čop, similar to Goethe, took into consideration old and modern literature in reflecting on and judging the literature of his nation and its history.

We can conclude that Čop, through the activities described, was namelessly hidden in a reference of Goethe's signifier "world literature". For this reason it is not significant that no mention of this expression has yet been found in his work: Matija Čop and France Prešeren through their actions between the years 1828 and 1835 adopted the essential properties of Goethe's Weltliteratur, which as an expression and a program only entered into the European public arena in that same period. Finally, let me nevertheless point out that it is possible that Čop was also familiar with explicit notes of Goethe's on world literature.

Goethe's fragmentary and ambivalent characterizations of the notion of "world literature" from 1827-31 are most prominently recorded in Eckermann's Conversations of Goethe from 1836, but for the most part they are "scattered in one 'work", i.e. his published and unpublished articles for Kunst und Altertum, a publication with which this "weimaraner Weltbewohner", in cooperation with other European journals ( $L^{\prime} E c o, L e$ Globe), implemented the program of literary cosmopolitanism (Koch 2002: 19, 231-233). In his correspondence Čop referred to particular issues of Goethe's journal from the period 1817-1827 (Kos 1986). It is thus probable that he also came across Goethe's first mention of Weltliteratur in Kunst und Altertum of 1827-1828. This word appears on page 131 of the first part of the sixth volume, in which Goethe inter alia publishes an article about Vincenzo Monti and Carlo TedaldiFores, to which Čop makes reference in his letter of 31 January 1828 to Savio. Goethe communicates the expression "world literature" in a generalizing segment of a note in which he somewhat narcissistically responds to the "historical drama" of Alexander Duval, Le Tasse, which he himself evidently influenced with his Torquato Tasso:

The extracts from French periodicals that I give are not merely intended to remind readers of myself and my writings: I have a higher aim of which I shall give a preliminary outline. We hear and read everywhere of the progress of the 
human race, of the wider prospects in world relationships between men. ... For my part I seek only to point out to my friends my conviction that a universal world literature [eine allgemeine Weltliteratur] is in process of formation in which we Germans are called to play an honourable part. The nations all look to us, they praise, blame, adopt and reject, imitate and distort, understand or misunderstand us, open or close their hearts towards us ... (Goethe, quoted in Strich 1949: 349).

Goethe's cosmopolitan characteristic of world literature is mentioned here only in passing, and even then - as already mentioned - with symptomatically nationalist undertones. In the same volume, part two (1828) of the journal Goethe mentions "world literature" again, on p. 396, when he sees in the Edinburgh Review an example of "journals, as they gradually reach a wider public, will contribute most effectively to the universal world literature we hope for"(Goethe, quoted in Strich 1949: 350). Weightier and more meaningful formulations of this cosmopolitan idea were published by Goethe in Kunst und Altertum in 1828, but the most influential was the one from Eckermann's Conversations of Goethe, which, however, only came out after Čop's death. It is thus questionable whether the remarks from 1827-28 attracted Čop's attention to the same degree as Goethe's article about Monti and Tedaldi-Fores ("Moderne Guelfen und Ghibellinen"), which appeared in 1827 on pages 164166 of the first part of volume six. In his correspondence, Čop referred on many occasions to Goethe's commentaries on European literature in Kunst und Altertum, and in the letter to Savio mentioned, in the midst of questions and information about modern Italian literature he asks him: "Do you know Meditazioni Poetiche by Carlo Tebaldi [sic!] Fores, which Goethe mentions favorably in the newspaper 'Kunst und Alterthum'?" (Čop 1986: 102, 105). As Kos relates, Goethe reports briefly on Tedaldi-Fores's poetological poetry, published in Cremona in 1825, in Kunst und Altertum already in 1826, as a polemic response to Monti's essay on mythology, and wrote more about it, in the context of the difference between the classicist and the Romantic relationship with mythology, in 1827 (cf. Kos 1986: 314). This is very close to the time of his first mention of Weltliteratur.

However, even if it is not possible to confirm that Čop was familiar with the expression Weltliteratur by 1828, when his and Prešeren's transfer of Romantic cosmopolitanism began, and although Goethe's word was not yet possible to find in Čop's vocabulary, there can be no doubt that he and Prešeren were already active in European developments which Goethe at the same time 
detected, recognized, and labeled with the concept of world literature - but they were determined by their peripheral position in the world system. It was only a question of time before "world literature" changed from actions to words in Slovenia as well, and as a concept it became the subject of conscious reflection, particularly in its relationship to national literature. Already in a note to a German elegy written on the occasion of Čop's death by the Austrian poet Franz Hermann von Hermannsthal, which appeared in Illyrisches Blatt on 18 June 1835, the word Weltliteratur was indirectly, through a particular figure of speech (hipalage), present in the expression "literary world". This phrase is significantly involved in the judgment that Cop's active role in world literature has been unjustly overlooked: "That he is known only in Carniola, his homeland, and not the entire literary world [die gesammte literarische Welt; emphasis added], has come about only because the constant demands of his studies and teaching, and his early death, left no time for the latter [the literary world] to come to know him, even as he was supporting its cause." (Hermannsthal 1835)

\section{References}

Bouterwek, F. 1801. Geschichte der Poesie und Beredsamkeit seit dem Ende des Dreizehnten Jahrhunderts. Erster Band. Göttingen: Johann Friedrich Röwer.

Casanova, P. 1999. La République mondiale des Lettres. Paris: Ed. du Seuil.

Chartier, R. 1994. The Order of Books: Readers, Authors, and Libraries in Europe between the Fourteenth and Eighteenth Centuries. Transl. Lydia G. Cochrane. Stanford, CA: Stanford UP.

Cohen, D. and M. O'Connor, eds. 2004. Comparison and History: Europe in Cross-National Perspective. New York and London: Routledge.

Čop, M. 1983. Pisma in spisi. [Letters and Writings] Ed. Janko Kos, trans. Janko Moder. Ljubljana: Mladinska knjiga.

- 1986. Pisma Matija Čopa. [M. Čop’s Letters] Vol. 1. Ed. Anton Slodnjak and Janko Kos. Ljubljana: SAZU.

Čelakovský, F. L. 1832. Kraginska literatura. [Carniolan Literature]. - Časopis Českého museum 6 (1832), pp. 443-454.

Damrosch, D. 2003. What Is World Literature? Princeton, N.J: Princeton Univeristy Press.

D'haen, T. 2011. The Routledge Concise History of World Literature. New York and London: Routledge.

Eckermann, J. P. 1998. Conversations of Goethe with Johann Peter Eckermann. Trans. John Oxenford. Cambridge, MA: Da Capo Press.

Even-Zohar, I. 1990. Polysystem Studies = Poetics Today 11.1 (1990).

- 2008. Culture Planning, Cohesion, and the Making and Maintenance of Entities. Beyond Descriptive Translation Studies: Investigations in Homage to Gideon Toury. Eds. 
JUVAN

Anthony Pym, Miriam Shlesinger and Daniel Simeoni. Amsterdam and Philadelphia: John Benjamins, pp. 277-292.

Goethe, J. W. 1974. Goethes Werke in Zwölf Bänden. Vol. 11: Schriften zu Kunst und Literatur. Berlin and Weimar: Aufbau-Verlag.

Hermannsthal, F. H. von. 1835. Dem Andenken des [... ] Mathias Zhóp. - Illyrisches Blatt (18.6. 1835), p. 113.

Hroch, M. 1993. From National Movement to the Fully-formed Nation. - New Left Review I/198 (1993), pp. 3-20.

Juvan, M. 2006. Dialogues between "Thinking” and "Poetry" and Theoretical-Literary Hybrids. - Primerjalna književnost 29, Special issue (2006), pp. 9-26.

- 2008. Ideologije primerjalne književnosti: perspektive metropol in periferij. [Ideologies of Comparative Literature: Metropolitan and Peripheral Perspectives] - Primerjalna književnost v 20. stoletju in Anton Ocvirk. Ed. Darko Dolinar and Marko Juvan. Ljubljana: Založba ZRC, pp. 57-91.

- 2009. Svetovni literarni sistem. [The World Literary System] - Primerjalna književnost 32.2 (2009), pp. 181-212.

- 2011a. Literary Studies in Reconstruction: An Introduction to Literature. Frankfurt/M. etc.: Peter Lang.

- 2011b. Romanticism and National Poets on the Margins of Europe: Prešeren and Hallgrímsson. Paper presented at the 4th Congress of REELC/ENCLS, Literary Dislocations, Skopje and Ohrid, 1-3 September, 2011.

http://vefir.hi.is/culturalsaints/?page_id=188

Kaelble, H. and J. Schriewer, eds. 2003. Vergleich und Transfer: Komparatistik in den Sozial-, Geschicts- und Kulturwissenschaften. Frankfurt and New York: Campus Verlag.

Kidrič, F. 1938. Prešéren: 1800-1838: življenje pesnika in pesmi. [P.: 1800-1838: The Lives of the Poet and the Poem] Ljubljana: Tiskovna zadruga.

- 1987. Matija Čop [1925]. Kidrič, Izbrani spisi 2. Ljubljana: Slovenska akademija znanosti in umetnosti. 147-164.

Koch, M. 2002. Weimaraner Weltbewohner: Zur Genese von Goethes Begriff 'Weltliteratur'. Tübingen: Niemeyer.

Kos, J. 1970. Prešeren in evropska romantika. [P. and European Romanticism] Ljubljana: Državna založba Slovenije.

- 1979. Matija Čop. Ljubljana: Partizanska knjiga.

- 1986. Uvod. Opombe. [Introduction. Notes] - Pisma Matija Čopa. Vol. 1. Ed. A. Slodnjak and J. Kos. Ljubljana: SAZU, pp. 9-29, 299-351.

Lacoue-Labarthe, P. and Nancy, J.-L. 1978. L'Absolu littéraire: Théorie de la littérature du romantisme allemand. Paris: Ed. du Seuil.

Leerssen, J. 2006a. National Thought in Europe: A Cultural History. Amsterdam: Amsterdam University Press.

- 2006b. Nationalism and the Cultivation of Culture. - Nations and Nationalism 12.4 (2006), pp. 559-578.

Moretti, F. 2000. Conjectures on World Literature. - New Left Review 1 (January February 2000), pp. 54-68. 
World Literature in Carniola

Moretti, F. 2003. More Conjectures. - New Left Review 20 (March - April 2003), pp. 7381.

Nemoianu, V. 2002. 'National Poets' in the Romantic Age: Emergence and Importance. Romantic Poetry. Ed. Angela Esterhammer. A Comparative History of Literatures in European Languages XVII. Amsterdam and Philadelphia: John Benjamins Publishing Company, pp. 249-255.

Nethersole, R. 2011. World Literature and the Library. - The Routledge Companion to World Literature. Eds. Theo D'haen, David Damrosch and Djelal Kadir. London and New York: Routledge, pp. 307-315.

Ocvirk, A. 1936. Teorija primerjalne literarne zgodovine. [A Theory of Comparative Literary History] Ljubljana: Znanstveno društvo, 1936.

Paternu, B. 1994. France Prešeren (1800-1849). Ljubljana: Znanstveni inštitut Filozofske fakultete.

Pizer, J. 2006. The Idea of World Literature: History and Pedagogical Practice. Baton Rouge: Louisiana State UP.

Prešeren, F. 1965. Zbrano delo. [Collected Works] Vol. 1. Ed. Janko Kos. Ljubljana: DZS.

Schlegel, F. von. 1815. Geschichte der alten und neuen Litteratur: Vorlesungen gehalten $z u$ Wien im Jahre 1812. Erster Theil. Wien: Schaumburg.

Schlegel, F. von. 1968. Dialogue on Poetry and Literary Aphorisms. Eds. and transl. Ernst Behler, Roman Struc. University Park: Pennsylvania State University Press.

Slodnjak, A. 1952. Prešeren, France. Slovenski biografski leksikon. Book 2, vol. 8. Ed. F. K. Lukman. Ljubljana: SAZU. 517-564.

- 1964. Prešernovo življenje. [P.'s Life] Ljubljana: Mladinska knjiga.

Staël, A.-L. G., Madame de. 1799-1800. De la littérature considérée dans ses rapports avec les institutions sociales. 2 vols. Paris: Maradan.

Strich, F. 1949. Goethe and World Literature. London: Rutledge \& Kegan Paul ltd.

Stritar, J. 1955. Zbrano delo. [Collected Works] Vol. 6. Ed. France Koblar. Ljubljana: DZS.

Štefan, R. 1985. Matija Čop v lvovskih Rozmaitościh. [M. Č. in Lvivian Rozmaitosci] Slavistična revija 33.4 (1985), pp. 407-418.

Žigon, A. 1914. Francè Prešéren: poet in umetnik. [F. P.: A Poet and Artist] Celovec: Družba sv. Mohorja.

- 1917. Čopova biblioteka. [Čop’s Library] Ljubljana: D. Hribar. 